\title{
Sustainable Development and Application of Bio - Energy in Coconut Plantations
}

\author{
H.A.J. Gunathilake ${ }^{1}$ and P.G. Joseph ${ }^{2}$
}

\begin{abstract}
Summary
One hectare of coconut land (156 palms ha ${ }^{-1}$ ) planted with gliricidia (2250 trees ha ${ }^{-1}$ into double rows in avenues of coconut), available natural pasture and outside supplied paddy straw coupled with six buffaloes were mixed into a farming model to examine total productivity and potential of green energy production by wood and biogas. Six buffaloes were maintained in a shed and the manure was collected for biogas generation. Biogas was purified from $\mathrm{H}_{2} \mathrm{~S}$ and the bio fuel was used to run a $0.75 \mathrm{hp}$ engine. Wood of gliricidia was used to energize a $3.5 \mathrm{~kW}$ gassifire-engine system for generating electricity.

Productivity of gliricidia in the $3^{\text {rd }}$ year was $4.5 \mathrm{~kg}$ wood (at $20 \%$ moisture) and $3.5 \mathrm{~kg}$ of fresh foliage per tree/year. Each buffalo produced an average of 622 liters of milk at the first lactation (for a period of 10 months) and value of a calf was Rs. 41244.00 at the age of 17 months.

Soils of the model were enriched by adding the effluent of biogas digester. The soil fertility (N, P, $\mathrm{K}, \mathrm{Mg}$, moisture holding capacity) improved significantly over soils sampled outside the model. The effluent of biogas was more fertile than dried buffalo dung. As a result, nut yield of coconut palms increased from 30 to 60 nuts palm ${ }^{-1}$ year $^{-1}$ over a period of two years.

In green energy production, the dung of six buffaloes passed through a $0.5 \mathrm{~kW}$ biogas-engine system generator produced $2 \mathrm{kwh}$ of electricity per day which if generated by diesel driven generator would require 0.9 liters of diesel. The annual generation of electricity from the biogas amounted to 700 $\mathrm{kwh}$. On the other hand, gliricidia wood of one hectare of coconut land was sufficient to energize $3.5 \mathrm{~kW}$ gassifire - engine - generator set for 1600 hours/year and this was equivalent to $5000 \mathrm{kwh}$ of electricity $(\mathrm{kWh})$. Thus, one hectare of coconut/gliricidia/natural pasture/paddy straw with six buffaloes was able to produce green energy equivalent to 5700 units of electricity $(\mathrm{kWh})$ or 2,565 liters of diesel, in addition to farm income derived from coconut, buffalo milk and other benefits of buffalo farming. The total return (coconut, selling of calves, buffalo milk and bio fertilizer) added up to Rs. 704,070 ha ${ }^{-1}$ year $^{-1}$. The feasibility of this model for adoption by small farmers of the coconut triangle in Sri Lanka is presented on the basis of this study.
\end{abstract}

Keywords: Coconut, Gliricidia, Bio-energy and Integrated farming system.

\footnotetext{
${ }^{1}$ Agronomy Division, Coconut Research Institute, Lunuwila, Sri Lanka.

${ }^{2}$ Alternative Energy Division, Ministry of Science and Technology, Sri Lanka.
} 


\section{Introduction}

Along with the price increases of fossil fuels and electricity, there is also an increased realization in Sri Lanka that traditional energy is going to be more expensive with time. Therefore, a greater utilization of alternatives has to be now actively promoted by the state to sustain the economic growth of the country. Further, self reliance is now acknowledged as an importance aspect in both food and energy in view of global political and economic developments.

Sri Lanka is fortunate enough to enjoy a major share of energy obtained from indigenous sources. However, the share of indigenous sources is shrinking rapidly, due to the ever growing energy demand resulting from the economic development of Sri Lanka. At present, the share of imported energy is $43 \%$ and is increasing steadily. Fossil fuel derived energy sources world wide are undergoing serious market upheavals at present and there is no hope of stability in the foreseeable future. In year 2008, the sharp increase of world oil prices saw Sri Lanka's oil imports consuming more than one third of all export earnings. Hence, development of alternative energy production systems within the plantation/agriculture sector is vital for national energy security.

Using sustainable agricultural methods the objectives of this study were to maximize farm income through an integrated (Coconut/ Gliricidia/ Paddy straw/ Cattle farming system using theoretical model given below (Figure, 1) and to develop a sustainable bio- energy system to meet energy requirement of household.

\section{Materials and methods}

This un-replicated study was conducted in a 22 years old coconut plantation (planted in $8 \mathrm{~m}$ $\mathrm{x} 8 \mathrm{~m}$ square patterns -156 palms $^{-1}$ ) at the Rathmalagara Estate, Madampe ( $\mathrm{IL}_{1}$ Low Country Intermediate Zone of Sri Lanka) of the Coconut Research Institute from January, 2007 to August, 2008. The mean annual rainfall of the location is around $1400 \mathrm{~mm}$ distributed over two seasons in a year. Mean annual temperature is $30^{\circ} \mathrm{C}$. The soil is the Boralu series and land suitability for coconut is Class 5 (Somasiri et al., 1994). Transmission of photo synthetically active radiation at the site under coconut palms was over $90 \%$ at mid day on a cloudless day.

\section{a). Coconut Plantation}

One hectare of coconut land was selected to establish this farming model. General maintenance was carried out and palms were fertilized without urea, $\mathrm{P}, \mathrm{K}$ and $\mathrm{Mg}$ were incorporated into the soil as practiced in organic farming.

\section{b). Gliricidia Inter Cultivation}

Double rows of Gliricidia were planted in the avenues of coconut palms at a $1 \mathrm{~m} \mathrm{x} 1 \mathrm{~m}$ spacing (2250 trees $\left.\mathrm{ha}^{-1}\right)$. Gliricidia trees were lopped periodically ( 8 months) for leaf and wood.

\section{c). Cattle Shed}

The cattle shed was designed to accommodate 12 buffaloes however, only six buffaloes were maintained in this study. The construction cost was Rs. 185,000.00. Water pipe lines were placed above the animals to moisten buffaloes by spraying water during very warm periods of the day.

\section{d). Bio Gas Unit}

A bio-gas unit of $12 \mathrm{~m}^{3}$ was constructed to generated bio gas from cattle dung. The material cost of constructing the bio gas unit was Rs. 47,500.00 and the labor cost was Rs. $23,000.00$. The pressure of the gas after 20 hours of closing the pipe was $30 \mathrm{~cm}$. W.G.

\section{e). Feeding Buffaloes}

Female buffaloes were selected and initial weight range was approximately $600 \mathrm{~kg}$ per animal. For an animal of $600 \mathrm{~kg}$ weight, $5.5 \mathrm{~kg}$ of animal feed (dry weight basis) was given daily. The feed consist of a mixture of $30 \%$ Gliricidia, $30 \%$ paddy straw and $40 \%$ pasture.

\section{f). Buffalo Maintenance}

Initially, the buffaloes were at the cattle shed throughout the day but subsequently it was realized it is inconvenient for animals during the dry season (March - April and July - 
September). Considering health aspects, buffaloes were released for 2 hours to the adjacent field during the day.

\section{g). Model Farmer}

The person selected for the project was Mr. Nimal Bandra who was a temporary watcher looking after 20 ha of the estate. His family consists of 3 children and 3 adults and all of them ware engaged in farming activity of the model. Hence, the model was maintained using family labor.

\section{h). Use of Bio Gas}

Bio gas generated from the digester was passed through a pipe placed with iron oxide particles to remove the $\mathrm{H}_{2} \mathrm{~S}$. The purified biogas was directed to a $0.5 \mathrm{~kW}$ engine generator to produce $500 \mathrm{~W}$ electricity. This electricity was used for daily household requirements.

\section{i). Wood gassifire}

Wood of gliricidia (at 20\% moisture level) was used to energize a $3.5 \mathrm{~kW}$ gassifire engine generator located at Kohomba Estate, Kakkapalliya.

\section{Results}

\section{Productivity of Gliricidia}

At the initial stage, the productivity of a gliricidia tree was $1.9 \mathrm{~kg}$ of foliage and $1.0 \mathrm{~kg}$ of wood/tree/year (Table 1). It was observed that both outputs increased with the present tree management system Gliricidia produced more wood weight than foliage.

\section{Calving and milk yield of buffaloes}

Out of the six female buffalo herd, five females delivered 4 males and one female calves. Body weight of all calves after sixteen months of calving exceeded $270 \mathrm{~kg}$ (Table 2). Average selling price of a calf was Rs. 41,244.00 based on a formula given by the National Livestock Development Board.
First lactation period was observed as approximately 10 months. During this period, each female buffalo produced an average of 622 liters of buffalo milk/ yr or/10 months? (Table $3)$. The maximum milk production level was 683 liters per animal/10 mths/yr? at the first lactation.

\section{Soil Improvement}

Soil analysis for several chemical and physical properties was comparatively carried out using soil in the system where animal movement and residues of the system were added, and soil outside the model for comparison (Table 4). The electrical conductivity, soil bulk density, moisture holding capacity of soil in the model were clearly elevated to improve quality of the soil in the model area. This was noticed at soil depths of $15 \mathrm{~cm}$ and $30 \mathrm{~cm}$.

At the $15 \mathrm{~cm}$ soil depth levels of nitrogen in system has elevated by $30 \%$ over soils outside the system. Similarly improvement of phosphorous and potassium were 1 and 3 folds respectively, $\mathrm{Mg}$ also showed a $66 \%$ increase in soils of the system. At a depth of $30 \mathrm{~cm} \mathrm{~N}, \mathrm{P}, \mathrm{K}$ and $\mathrm{Mg}$ were higher than those at a depth of 15 $\mathrm{cm}$. (Table 5) For example, $\mathrm{N}$ and $\mathrm{P}$ recorded a 2 fold and $\mathrm{K}$ recorded a 4.7 fold increase. Soil $\mathrm{pH}$ was slightly reduced in the soil within the system.

\section{Analysis of buffalo dung and biogas effluent}

$\mathrm{N}, \mathrm{P}, \mathrm{K}, \mathrm{Mg}, \mathrm{pH}$ and electrical conductivity were measured in the manure collected from the dairy and those passed through the biogas unit as effluent (Table 6). $\mathrm{N}$ and $\mathrm{P}$ levels were doubled in the effluent. The $\mathrm{K}$ level of effluent was also higher than in the dung. $\mathrm{Mg}$ was slightly lower in samples of effluent.

\section{Nut yield improvement}

At the commencement of the experiment the average yield of a coconut palm was below

Table 1. Fresh foliage and wood yield of gliricidia in the bio-energy system at Ratmalagara

\begin{tabular}{|l|c|c|c|c|c|c|}
\hline \multirow{2}{*}{} & \multicolumn{2}{|c|}{ Year 01 } & \multicolumn{2}{c|}{ Year 02 } & \multicolumn{2}{c|}{ Year 03 } \\
\cline { 2 - 6 } & $\mathrm{kg} /$ tree/yr & $\mathrm{kg} / \mathrm{ha} / \mathrm{yr}$ & $\mathrm{kg} / \mathrm{tree} / \mathrm{yr}$ & $\mathrm{kg} / \mathrm{ha} / \mathrm{yr}$ & $\mathrm{kg} / \mathrm{tree} / \mathrm{yr}$ & $\mathrm{kg} / \mathrm{ha} / \mathrm{yr}$ \\
\hline
\end{tabular}




\begin{tabular}{|l|c|c|c|c|c|c|}
\hline Foliage (fresh) & 1.9 & 4275 & 2.8 & 6300 & 3.9 & 8775 \\
\hline Wood (as 20\% moisture) & 1.0 & 2250 & 4.0 & 9300 & 4.5 & 10125 \\
\hline Total & 2.9 & 6525 & 6.8 & 15300 & 8.4 & 18900 \\
\hline
\end{tabular}

Table 2. Productivity of the buffalo unit at Ratmalagara

\begin{tabular}{|c|c|c|c|}
\hline \multirow{2}{*}{ Female (mother No.) } & \multicolumn{2}{|c|}{$\mathbf{1}^{\text {st }}$ calf } & \multirow{2}{*}{ Selling price (Rs) } \\
\cline { 2 - 4 } & Age (months) & Live body weight (kg) & $38,080.00$ \\
30 & 14 & 272 & - \\
33 & No calving & - & $44,660.00$ \\
35 & 22 & 319 & $38,920.00$ \\
36 & 19 & 278 & $43,680.00$ \\
37 & 19 & 312 & $40,880.00$ \\
\hline
\end{tabular}

Table 3. Milk yield of the buffalo unit at Ratmalagara

\begin{tabular}{|c|c|}
\hline Animal number & Milk production (liters/ $\mathbf{1}^{\text {st }}$ calving (10 months) \\
\hline 28 & 616 \\
33 & 550 \\
35 & 670 \\
36 & 683 \\
37 & 595 \\
\hline
\end{tabular}

Table 4. Electrical Conductivity, pH, Bulk density and moisture holding capacity of soil in the model and soil outside the model at Ratmalagara

\begin{tabular}{|l|c|c|c|c|}
\hline \multirow{2}{*}{\multicolumn{1}{|c|}{ Soil sampling area }} & \multicolumn{2}{|c|}{ Electrical Conductivity } & \multicolumn{2}{c|}{ pH } \\
\cline { 2 - 5 } & 15cm depth & 30cm depth & 15cm depth & 30cm depth \\
\hline System (end) & $27.89 \mu \mathrm{s} / \mathrm{cm}$ & $33.39 \mu \mathrm{s} / \mathrm{cm}$ & 5.86 & 6.01 \\
\hline System (beginning) & $16.18 \mu \mathrm{s} / \mathrm{cm}$ & $17.31 \mu \mathrm{s} / \mathrm{cm}$ & 6.29 & 6.10 \\
\hline
\end{tabular}

\begin{tabular}{|l|c|c|c|}
\hline & \multirow{2}{*}{ Soil sampling area } & \multicolumn{2}{|c|}{ Soil moisture content (\%) } \\
\cline { 3 - 4 } & Bulk density $\left(\mathbf{g} / \mathbf{c m}^{\mathbf{3}}\right)$ & $\mathbf{1 5 c m}$ depth & 30cm depth \\
\hline System (end)) & 1.51 & 8.27 & 8.66 \\
\hline System (beginning) & 1.56 & 6.80 & 6.93 \\
\hline
\end{tabular}

Table 5. Soil nutrient levels (N, P, K, Mg, Ca and $\mathrm{Na}$ ) within the model and outside at Ratmalagara

\begin{tabular}{|l|c|c|c|c|c|c|}
\hline \multirow{2}{*}{ Soil sampling area } & \multicolumn{2}{|c|}{$\mathbf{N}(\mathbf{m g} / \mathbf{k g})$} & \multicolumn{2}{c|}{$\mathbf{P}(\mathbf{m e q} / \mathbf{1 0 0 g})$} & \multicolumn{2}{c|}{ K (meq/100g) } \\
\cline { 2 - 7 } & $\begin{array}{c}\mathbf{1 5 c m} \\
\text { depth }\end{array}$ & $\begin{array}{c}\mathbf{3 0 c m} \\
\text { depth }\end{array}$ & $\begin{array}{c}\mathbf{1 5 c m} \\
\text { depth }\end{array}$ & $\begin{array}{c}\mathbf{3 0 c m} \\
\text { depth }\end{array}$ & $\mathbf{1 5 c m}$ depth & $\begin{array}{c}\mathbf{3 0 c m} \\
\text { depth }\end{array}$ \\
\hline System (end) & 139.6 & 2399.3 & 23.99 & 8.16 & 1.101 & 0.891 \\
\hline
\end{tabular}




\begin{tabular}{|l|c|c|c|c|c|c|}
\hline System (beginning) & 1068.81 & 1103.68 & 11.43 & 4.14 & 0.260 & 0.189 \\
\hline Soil sampling area & Mg (meq/100g) & Ca (meq/100g) & \multicolumn{2}{|c|}{ Na (meq/100g) } \\
\cline { 2 - 7 } & $\begin{array}{c}\mathbf{1 5 c m} \\
\text { depth }\end{array}$ & $\begin{array}{c}\mathbf{3 0 c m} \\
\text { depth }\end{array}$ & $\begin{array}{c}\mathbf{1 5 c m} \\
\text { depth }\end{array}$ & $\begin{array}{c}\mathbf{3 0 c m} \\
\text { depth }\end{array}$ & $\mathbf{1 5 c m}$ depth & $\begin{array}{c}\mathbf{3 0 c m} \\
\text { depth }\end{array}$ \\
\hline System (end) & 1.109 & 0.908 & 1.545 & 1.273 & 0.026 & 0.025 \\
\hline System (beginning) & 0.667 & 0.285 & 1.152 & 0.518 & 0.040 & 0.022 \\
\hline
\end{tabular}

Table 6. Buffalo dung and gas unit slurry analysis at Ratmalagara

\begin{tabular}{|l|l|l|l|l|l|l|}
\hline & $\mathbf{N} \%$ & $\mathbf{P \%}$ & $\mathbf{K} \%$ & $\mathbf{M g \%}$ & $\begin{array}{l}\mathbf{E C} \\
\boldsymbol{\mu} / \mathbf{c m}\end{array}$ & $\mathbf{p H}$ \\
\hline Cow dung & 1.31 & 0.56 & 0.93 & 0.64 & 3.41 & 7.14 \\
\hline Effluent & 2.96 & 1.08 & 1.02 & 0.52 & 3.07 & 6.69 \\
\hline
\end{tabular}

30 nuts palm $^{-1}$ year $^{-1}$. After 2 years of field activities, the average yield was estimated as 60 nuts palm ${ }^{-1}$ year $^{-1}$ and button nut setting indicated that the potential yield of 2009 ( $3^{\text {rd }}$ year $)$ would be over 80 nuts palm ${ }^{-1}$ year $^{-1}$.

\section{Energy production}

\section{Biogas generation}

Biogas generated from the unit was sufficient to energize a $0.5 \mathrm{~kW}$ capacity engine for 4 hours per day giving output of $2 \mathrm{kwh}$ of electricity. This is equivalent to 0.9 liters of Diesel, as $1.8^{3}$ volume of biogas was generated per day.

\section{Energy generation by wood}

In the third year, average wood production of a gliricidia tree was $4.5 \mathrm{~kg}^{-1} \mathrm{tre}^{-1}$ year $^{-1}$ (at $20 \%$ moisture level). Hence, total wood productivity of 1.0 ha system was $10,125 \mathrm{~kg}$ and this was sufficient to run a $3.5 \mathrm{~kW}$ gassifire - engine generator set for 1600 hours generating 5000 $\mathrm{kWh}$ of electrical energy.

\section{Total energy output of the model}

Applicable bio energy was by biogas and wood. In the third year of the system, this was equivalent 5700 electricity $\mathrm{kWh}$ or 2,565 liters of diesel per year.

\section{Gross return of the model}

As presented in the Table 7, the direct outturn of the model were coconuts, buffalo milk, calves and energy (biogas and gliricidia wood). On the other hand, biogas effluent was the fertilizer for coconut; hence it saved costs of chemical fertilizer, annually estimated as Rs. 45,000.00 per hectare of coconut.

Table 7. Estimated gross return of the model at the $3^{\text {rd }}$ year including value of energy

\begin{tabular}{|l|l|l|r|}
\hline \multicolumn{1}{|c|}{ Item } & \multicolumn{1}{|c|}{ Actual yield } & \multicolumn{1}{|c|}{ Unit price (Rs) } & $\begin{array}{c}\text { Gross return } \\
\text { (Rs/ha/Year) }\end{array}$ \\
\hline $\begin{array}{l}\text { Coconut } \\
\text { Selling of calves }\end{array}$ & $\begin{array}{l}9000 \text { nuts/ha } \\
5 \text { calves }\end{array}$ & $\begin{array}{l}\text { Rs. 20/= per nut } \\
\text { Rs. 41,244/= at the age of 16 } \\
\text { months }\end{array}$ & $\begin{array}{l}180,000.00 \\
206,220.00 \\
\text { Buffalo milk }\end{array}$ \\
& $\begin{array}{l}\text { R2. 30/= per liter } \\
150 \text { palms /ha }\end{array}$ & $93,300.00$ \\
\hline
\end{tabular}




\begin{tabular}{|l|l|l|r|}
\hline $\begin{array}{l}\text { Saving of fertilizer for } \\
\text { coconut } \\
\begin{array}{l}\text { Value of energy eqaulent } \\
\text { diesel }\end{array}\end{array}$ & $\begin{array}{l}\text { Rs. 300 / X per coconut palm } \\
\text { Rs. 70/= per liter }\end{array}$ & $45,000.00$ \\
\hline Total gross return & & & $179,550.00$ \\
\hline
\end{tabular}

Figure 1. Theoretical Model prior to the trials consists of buffalo, gliricidia, paddy, straw and natural grasses to produce green energy

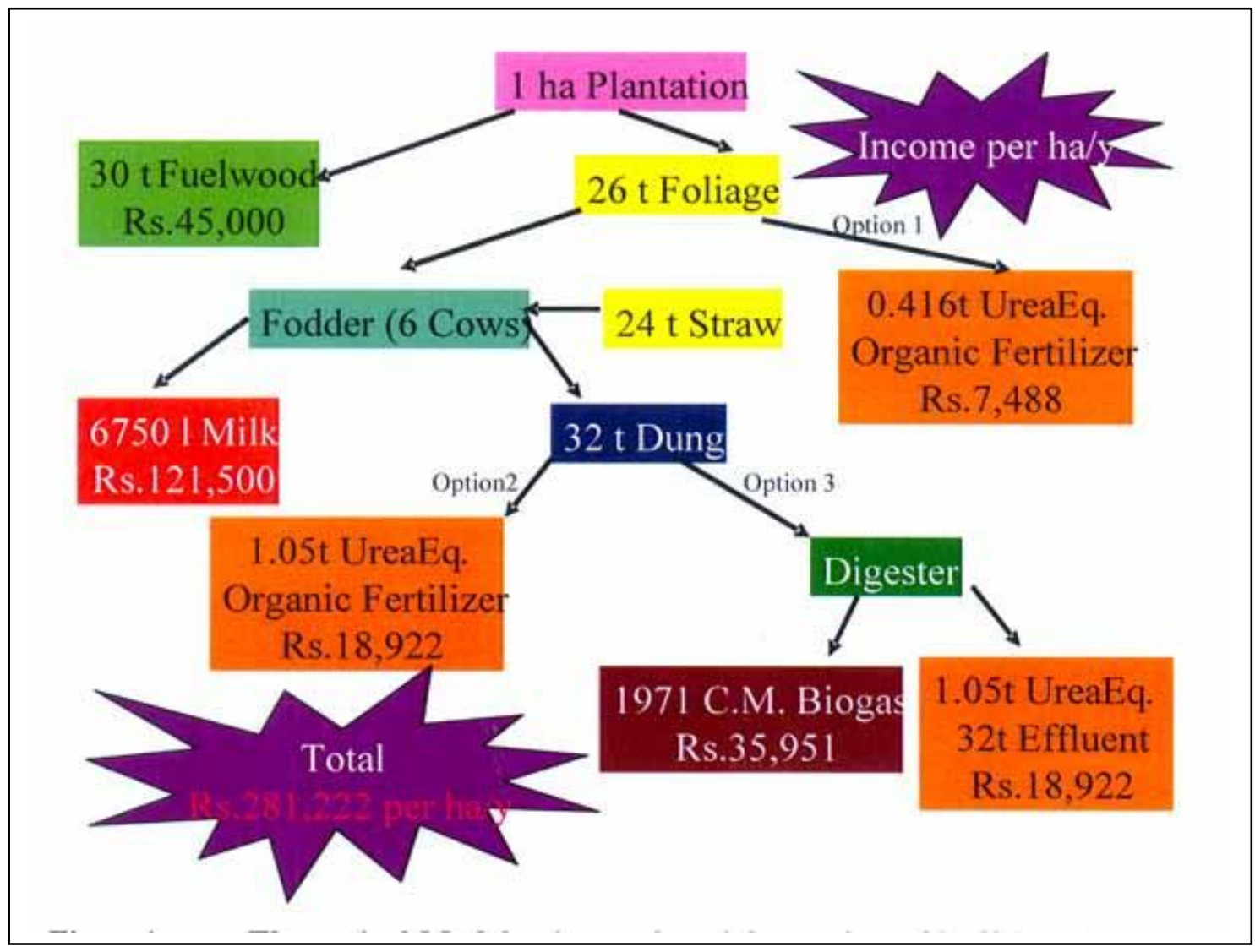

Discussion

Coconut production in our country is predominantly dependant on small and marginal farmers. More than 700,000 families grow coconut for their livelihood. Coconut utilizes only $25 \%$ of the land area and $40-45 \%$ of the incident light. Under mono cropping coconut, resources such as sunlight, soil water, plant nutrients, and space are underutilized; hence profit maximization of unit area of land is the main constraint (Maheswarappa et al., 1998).

Integrated farming is combine's crop production with livestock. The livestock enterprise is complementary to crop production programs so as to provide a balanced and productive system of farming (Liyanage and Fernando, 1991). In a hectare of coconut land five to six cows can be maintained. On an average, $15-25 \mathrm{~kg}$ of fresh manure can be 
obtained per day from each animal (Maheswarappa et al., 1998).

In tropical agriculture there are two key issues; sustainable management of soil fertility and sustainable farm energy generation. To compete with global economic scenarios, maximization of farm income should be of high priority. Before commencement of this study (year 2005), a theoretical model was made (Figure, 1) assuming that Rs. 281,222 ha $^{-1}$ year $^{-1}$ could be earned from one hectare of coconut based buffalo farming integrated with gliricidia, in-situ pasture, paddy straw and a bio gas digester.

In the third year of implementation, installment for a gassifire or generator, (excluding value of generated electricity) actual income of one coconut hectare was Rs, 572,815 (Figure, 2) from coconut, milk, calves, bio fertilizers, fuel wood and biogas for house hold use. This was almost a $100 \%$ increase of the initial estimation, indicating the success of the model. Of the total income of the model, $1 / 3$ was by coconut and $2 / 3$ was by milk, calves, wood, bio fertilizer and biogas. Income by selling of calves was double the income of milk indicating scarcity of improved breeds of buffaloes (Fig 2). In general income generation in monoculture coconut plantation could be increased by 3.5 fold by integrated buffalo farming itself.

Renewable energy sources, unlike fissile fuels, can be used without ever being used up. Biogas and biomass (wood) are categorized as renewable energy sources. It pollutes less, makes a county less dependence on imported fuel, requires less foreign currency and has almost no net carbon dioxide emission (Lomborg, 2005). The technology applied in the model is cheap, easy to repair and ideally suited for villages and remote regions. Moreover, there is no negative social cost as involved with fossils fuels. As experienced, country's industrial sector is seriously affected by high costs of energy and this study shows that energy for coconut based industries could be met by this model (eg. Coir and copra processing). Household energy requirements could also be supplemented easily only by biogas either directly or by generating electricity. The direct use of biogas has many disadvantages such as low output, smell and the absence of the possibilities to operate household equipment such as refrigerators. In energy usage, the most convenient and popular is electricity or liquid fuel. It is important to note that in this model, the end-energy product was electricity and it was evident that it is possible to generate 5700 electricity units $(\mathrm{kWh})$ or equivalent to 2,565 liters of diesel from a hectare of coconut land. Therefore, any coconut grower will be able to make his own energy plan depending on his coconut extent and his choice of coconut based industry. Such enterprises, undoubtly reduce energy dependence of the country by increasing national renewable energy production.

A significant development in the model which was selection of buffalo as the animal component. Buffaloes are identified as good ruminants to feed roughage, as they are able to convert many cellulose feeds into valuable items such as milk, meat etc (Liyanage and

Figure 2. Updated Income from 1 ha Coconut/Gliricidia Plantation Integrated with a Buffalo Dairy with no involvement for power generation

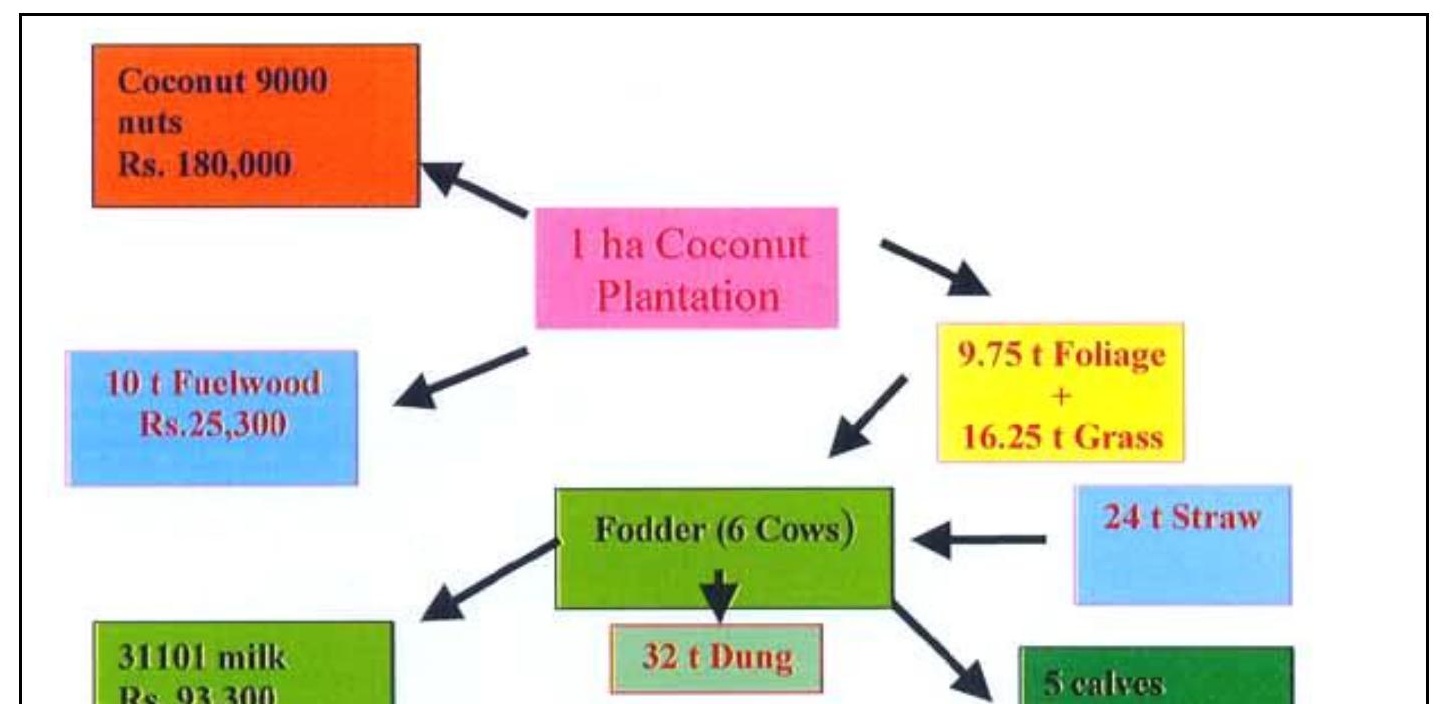


Fernando, 1991). However, their body temperature is higher than cows and hence wallowing is needed. This was overcome by modifying the shed and moisting animals frequently. As a result, animal health and facility to produce milk was observed to be excellent. It could be stated them buffaloes could be moved from muddy fields to highly convenient sheds by artificial drizzling.

Gliricidia is now popular as the 4th plantation crop due to its multiple uses (Gunathilake and Wasantha, 2004). It has the ability to fix aerial $\mathrm{N}$ and enriched soils by green manuring. On the other hand, it is a valuable animal feed for protein. In this model, leaves of gliricidia mixed with paddy straw, was the main feed for buffaloes, and it seems to be an ideal animal feed. Therefore it was evident that good animal feed can be blended locally for high production of milk and meat in-addition to additional benefits of manure and its recycling chain in agriculture.

Management of soil fertility in coconut plantations is now being addressed to sustain coconut yields economically. As at present, soil degradation is obvious. Application of chemical fertilizers is not the answer for management of sustainable soil fertility. Hence, application of organic fertilizers for coconut as well as other crops is becoming a popular feature. On many occasions, cattle dung and other similar sources are called as organic fertilizers, however it seems to be incorrect and these are virtually natural fertilizers. Today's need is not natural fertilizers, but fertilizer with easily available nutrients. Therefore, all natural fertilizers should be processed into chemical forms if possible by normal processes. In this model, gliricidia and paddy straw were fed to buffaloes to make manure and the manure was passed through a biogas digester which gave biogas slurry/effluent. The plant chemical parameters of effluent are higher than in pure manure (Table, 6) and further analysis showed that plant nutrients in effluent are easily available forms of nutrients such as $\mathrm{N}, \mathrm{P}, \mathrm{K}$. Microorganisms were not analyzed in this study but it is obvious their association with effluent should be greater than for dry manure. Therefore, further studies are suggested on the role of micro-organisms in effluent and cow dung (biogas benefits). No doubt, that this would be the reason for doubling nut yield in a short time. Therefore, it is now 
worthy to consider recommendations of application of cattle dung as a natural fertilizer for coconut, which seem to be inefficient compared to its process from biogas effluent. Studies show that $2 / 3$ of $N$ is lost by improper compost application to soil, but the process of biogas is in vitro. Therefore $\mathrm{N}$ losses would be minimal. Due to continuous activities of the model, all chemical and physical parameters of soil were improved (Table 4 and 5). Soil of the model is classified in the Land Suitability Class 5 (Somasiri et al., 1994) and potential yield of this soil is stated as 30 nuts palm ${ }^{-1}$ year $^{-1}$ or below. However, in the model, nut yield of palm could be increased up to 60 nuts palm ${ }^{-1}$ year $^{-1}$ and then to 80 nuts or more. This is evidence that soils of low land suitability classed could be elevated to higher levels by improved coconut land management systems as practiced in this model by adopting in integrated systems with combinations of livestock and crop.

\section{Conclusion}

There is a significant potential in coconut lands increase crop productivity and to generate ecologically sound green (bio) energy. In national food security, milk production is given high priority due to high cost of imported packs of milk powder. In this regard, role of cattle/buffaloes and other ruminants play a vital role by producing natural fertilizers in addition to milk. It is now well accepted that without ruminants there is no sustainability in agricultural production. This study, proved that integration of coconut, gliricidia, pasture and paddy straw coupled with buffaloes is able to increase productivity and sustainability of coconut lands. The interesting feature is the production of a bioenergy system and the highest outturn was from the energy due to mismanagement of energy issues in the country. All necessary technical directions are given here to develop much bioenergy which is needed among local village faming communities. In conclusion it is suggested that "Bio-energy villages" are developed to achieve independence not only in democracy but also in national energy security.

\section{Acknowledgement}

The authors wish to thank Director Coconut Research Institute for granting permission to present the data of the farming model. The assistance given by Mr. H.A. Abeysoma, Dr. S.H.S. Senerathna, Mr. Manjula is gratefully acknowledged. Vidya Jothi Dr. Ray Wijewardena assisted greatly to collect data from wood based gassifire at Kohombe Estate. Dr. A. Tennakoon, Head of Soils and Plant Nutrition Division of the CRI is also acknowledged for helping soils and sample analysis. Our sincere thanks to Secretary of the Ministry of Science and Technology for financial assistance to initiate the project. Finally we thank Mrs. Tharanga Dilani Danapala for typing the manuscript.

\section{References}

Gunathilake, H.A.J. and Wasantha, H.G. (2004). Gliricidia for production of green manure and green energy in coconut plantations. Proceedings of the first Symposium on Plantation Crop Research, BMICH, July 8-9, 2009: 43-52.

Liyanage, M. de. S. and Fernando, D.N.S. (1991). Role of legume based pasture, tree fodder and paddy straw in coconut/cattle farming system in Sri Lanka. Paper presented at the International Seminar on Livestock and Feed Development in the Tropics, 21-25 October, 1991, Malony Indonesia: 56-64. 
Cord 2009, 25 (2)

Lomborg, B. (2005). The Skeptical Environmentalist, Measuring the Real State of the World, Cambridge University Press: 118-135.

Maheswarappa, H.P., Dhanapal, R., Vidhan Singh, T. and Hegde, M.R. (1998). Integrated coconut based farming systems for sustainable agriculture. Indian Coconut Journal, Vol. XXIX No: 7-10.

Somasiri, L.L.W., Nadaraja, N. Amarasinghe, L. and Gunathilake, H.A.J. (1994). Land suitability assessment of coconut growing area in the coconut triangle. Occasional Publication Series No.3, Coconut Research Institute, Lunuwila, Sri Lanka. 
